\title{
Modulating factors of the abundance and distribution of Achelous spinimanus (Latreille, 1819) (Decapoda, Portunoidea), a fishery resource, in Southeastern Brazil
}

\begin{abstract}
Aline Nonato de Sousa ${ }^{\text {Corresp., }}{ }^{1}$ ， Giovana Bertini ${ }^{1,2}$ ， Fabiano Gazzi Taddei ${ }^{1,3}$, Rogério Caetano Costa ${ }^{1,4}$, Thiago Elias da Silva ${ }^{1}$, Adilson Fransozo ${ }^{1}$

${ }^{1}$ Núcleo de Estudos em Biologia, Ecologia e Cultivo de Crustáceos - NEBECC, Universidade Estadual Paulista "Júlio de Mesquita Filho" - UNESP, Botucatu, São Paulo, Brazil

2 Laboratório de Biologia e Cultivo de Crustáceos - LABCRUST, Universidade Estadual Paulista "Júlio de Mesquita Filho" - UNESP, Registro, São Paulo, Brazil

3 Laboratório de Estudos de Crustáceos Amazônicos - LECAM, Universidade do Estado do Amazonas - UEA, Parintins, Amazonas, Brazil

4 Laboratório de Biologia de Camarões Marinhos e de Água Doce - LABCAM, Universidade Estadual Paulista "Júlio de Mesquita Filho" - UNESP, Bauru, São Paulo, Brazil
\end{abstract}

Corresponding Author: Aline Nonato de Sousa

Email address: alinensousa1@ibb.unesp.br

This is the first study to examine how different environmental factors may influence the distribution of swimming crab Achelous spinimanus across geographically distant and distinct habitats. We analyzed the influence of bottom water temperature and salinity, sediment texture and organic matter content) on the spatiotemporal distribution of $A$. spinimanus. The crabs were collected from January 1998 until December 1999 by trawling with a shrimp fishing boat outfitted with double-rig nets. The sampling took place in Ubatumirim (UBM), Ubatuba (UBA) and Mar Virado (MV) bays, located in the northern coast of São Paulo State (Brazil). These three bays were chosen as they differed in many physiographic features. We captured 1911 crabs (UBM = 351; UBA = 1509; MV = 51), and there were significant differences in abundance between bays and between stations. The distribution of $A$. spinimanus was primarily associated with sediment features: abundance was higher in stations with sandy sediments classified as gravel, very coarse sand, and intermediate sand. Portunoidea usually burrow in the sediment for protection against predators and to facilitate the capture of fast prey. In addition, the station with the highest abundance of $A$. spinimanus was also naturally protected from fishing activities, and composed of heterogeneous sediment, in terms of grain size. Hence, the combination of a favorable sediment heterogeneity and protection from fishery activities seemed to be effective modulators of the abundance and distribution of $A$. spinimanus in these bays. 
$6{ }^{1}$ Núcleo de Estudos em Biologia, Ecologia e Cultivo de Crustáceos (NEBECC), Instituto de 7 Biociências de Botucatu, Universidade Estadual Paulista "Júlio de Mesquita Filho", Botucatu, 8 São Paulo, Brasil;

9 2Laboratório de Biologia e Cultivo de Crustáceos (LABCRUST), Universidade Estadual Paulista

\section{Modulating factors of the abundance and distribution of Achelous spinimanus (Latreille, 1819) (Decapoda, Portunoidea), a fishery resource, in Southeastern Brazil}

\begin{abstract}
Aline Nonato de Sousa' ${ }^{1}$, Giovana Bertini ${ }^{1,2}$, Fabiano Gazzi Taddei 1,3, Rogério Caetano Costa 1,4,
\end{abstract} Thiago Elias da Silva ${ }^{1} \&$ Adilson Fransozo ${ }^{1}$

"Júlio de Mesquita Filho", Registro, São Paulo, Brasil;

${ }^{3}$ Laboratório de Estudos de Crustáceos Amazônicos (LECAM), Universidade do Estado do Amazonas, Parintins, Amazonas, Brasil;

${ }^{4}$ Laboratório de Biologia de Camarões Marinhos e de Água Doce (LABCAM), Universidade Estadual Paulista "Júlio de Mesquita Filho", Bauru, São Paulo, Brasil;

Corresponding author: Aline Sousa ${ }^{1}$

E-mail address: alinensousa1@ibb.unesp.br 
32

ABSTRACT

This is the first study to examine how different environmental factors may influence the distribution of swimming crab Achelous spinimanus across geographically distant and distinct habitats. We analyzed the influence of bottom water temperature and salinity, sediment texture and organic matter content) on the spatiotemporal distribution of $A$. spinimanus. The crabs were collected from January 1998 until December 1999 by trawling with a shrimp fishing boat outfitted with double-rig nets. The sampling took place in Ubatumirim (UBM), Ubatuba (UBA) and Mar Virado (MV) bays, located in the northern coast of São Paulo State (Brazil). These three bays were chosen as they differed in many physiographic features. We captured 1911 crabs $(\mathrm{UBM}=351 ; \mathrm{UBA}=1509 ; \mathrm{MV}=51)$, and there were significant differences in abundance between bays and between stations. The distribution of $A$. spinimanus was primarily associated with sediment features: abundance was higher in stations with sandy sediments classified as gravel, very coarse sand, and intermediate sand. Portunoidea usually burrow in the sediment for protection against predators and to facilitate the capture of fast prey. In addition, the station with the highest abundance of $A$. spinimanus was also naturally protected from fishing activities, and composed of heterogeneous sediment, in terms of grain size. Hence, the combination of a favorable sediment heterogeneity and protection from fishery activities seemed to be effective modulators of the abundance and distribution of $A$. spinimanus in these bays.

\section{INTRODUCTION}

The abundance and distribution of organisms in the environment, as a rule, vary according to the variation of environmental resources (Organista et al., 2005). In this sense, Organista et al. (2005) assumed that individuals may tolerate a wide variation of a given environmental factor (eurytopic) or not (stenotopic). Even slight variations in environmental conditions might lead to different behavioral, morphological, and physiological responses (Thompson, 1991). Moreover, predator-prey relationships and intra- or interspecific competition may also alter the seasonal distribution of different species (Pinheiro, Fransozo \& NegreirosFransozo, 1996).

Studies on the distribution of benthic organisms have shown the importance of environmental factors such as temperature and salinity, sediment texture, and organic matter 
62 (Abelló, Valladares \& Castellón, 1988; Fariña, Freire \& González-Gurriarán, 1997; Cartes et al., 63 2007; Bertini, Fransozo \& Negreiros-Fransozo, 2010; Fransozo et al., 2016; Costa et al., 2016). According to Mahiques (1995), the southeastern Brazilian coast, and especially within the

Due to its high productivity, the Ubatuba region is commonly exploited by shrimp fishing industry (Mantelatto et al., 2016) targeting mainly pink shrimp Farfantepenaeus brasiliensis (Latreille, 1817) and F. paulensis (Pérez-Farfante, 1967), and sea bob shrimp Xiphopenaeus kroyeri (Heller, 1862) (D'incao, Valentini \& Rodrigues, 2002). Fishing by trawling is considered a destructive method for the benthic communities (Branco \& Fracasso, 2004), and it often leads to a decrease in fishing stocks. When more profitable species become scarce, fishing fleets search for alternative resources. This is the case of Achelous spinimanus (Latreille, 1819) which has become a new target of the fishing fleets (Santos, Negreiros-Fransozo \& Padovani, 1995; Branco, Lunardon-Branco \& Souto, 2002; Ripoli et al., 2007), given its body size and particular taste, which are favorable to human consumption.

Besides its economic potential, A. spinimanus, as well as other swimming crabs, play a fundamental role in the trophic web of coastal ecosystems, being predators of various invertebrate groups (Branco \& Verani, 1997). In the northern coast of São Paulo State, the representatives of Portunoidea are abundant and more diverse than other brachyurans (Braga et al., 2005; Bertini, Fransozo \& Negreiros-Fransozo, 2010). In this region, several studies have investigated the relationship between these crustaceans and environmental variables. For instance, Santos, Negreiros-Fransozo \& Fransozo, (1994) and Pinheiro, Fransozo \& NegreirosFransozo (1996) observed that the distributions of A. spinimanus and Arenaeus cribarius (Lamarck, 1818), respectively, were associated with sediment texture. Pinheiro, Fransozo \& Negreiros-Fransozo, (1997), Santos (2000), Chacur \& Negreiros-Fransozo (2001), Andrade et al. (2013), Andrade et al. (2014), Lima et al. (2014), Martins et al. (2014), and Antunes et al. (2015) related the distribution of Portunoidea with bottom temperature. 
92

93

94

95

96

97

98

104

105

106

107

108

109

110

111

112

113

114

115

116

117

118

119

120

121

122

Considering that $A$. spinimanus is a new fishing resource, more studies on its biology are necessary to establish management strategies aiming at a more controlled fishing and sustainable use. Although Santos, Negreiros-Fransozo \& Fransozo, (1994) and Santos (2000) determined the environmental factors influencing the distribution patterns of A. spinimanus in Fortaleza Bay (Ubatuba, SP), there have been no comparative studies addressing its distribution patterns in different areas, with different environmental features, at the same time. Aiming to fill this gap, we compared the distribution of $A$. spinimanus in three bays having distinct physiographical features. This comparison provided information on $A$. spinimanus distribution over a greater range of environmental conditions, expanding the knowledge from previous works conducted in only one bay. Furthermore, our goal was to indicate, by means of innovative and robust statistical analyses possible relationships between the spatiotemporal distribution of $A$. spinimanus and bottom water temperature and salinity, and sediment texture and organic matter content.

\section{MATERIAL \& METHODS}

\section{Study area}

Ubatuba is located in the northern coast of São Paulo State, Brazil. This region has a unique geological conformation and is known for its very irregular coast (Ab'saber, 1955). Ubatuba is influenced by three water masses: Coastal Water $\left(\mathrm{CW}\right.$ : temperature $\geq 20^{\circ} \mathrm{C}$; salinity $\leq$ 36), Tropical Water (TW: temperature $\geq 20^{\circ} \mathrm{C}$; salinity $\geq 36$ ), and South Atlantic Central Water $\left(\mathrm{SACW}\right.$ : temperature $\leq 18^{\circ} \mathrm{C}$; salinity $\leq 36$ ) (Castro-Filho, Miranda \& Myao, 1987; Odebrecht \& Castello, 2001; De Léo \& Pires-Vanin 2006). During late spring and early summer, the SACW penetrates into the coast's bottom layer and forms a thermocline over the inner shelf at depths of 10-15 m (Castro-Filho, Miranda \& Myao, 1987; Odebrecht \& Castello, 2001; De Léo \& PiresVanin 2006). During winter, the SACW retreats to the shelf break and is replaced by the CW, resulting in the absence of temperature stratification over the inner shelf during winter (Pires, 1992; Pires-Vanin \& Matsuura, 1993).

For this study we chose three bays in Ubatuba that have distinct physiographical features such as shapes and outfall directions: Ubatumirim, Ubatuba, and Mar Virado (Fig. 1). Ubatumirim Bay (UBM) has an outfall heading southwest, and many islands and marine rock banks (Prumirim and Porcos Pequenos Islands facing its entrance, and Couves Island) (Bertini, 
123 Fransozo \& Negreiros-Fransozo, 2010). Ubatuba Bay (UBA) has an east-facing outfall and a

124 seaward constriction formed by rocky projections forming a more shallow inner area and a 125 deeper outer area (>10 m deep) (Mahiques, 1995). Four rivers influence the sediment organic 126 matter content in this bay (Cetesb, 1996), especially during rainy seasons, when larger amounts 127 of sewage from the city of Ubatuba outflow into the area. Mar Virado Bay (MV) has a large 128 outflow that faces southwest, with the Mar Virado Island at the eastern side of the bay entrance. 129 The predominant substratum verified in this area comes from the sediment of two rivers, the 130 Lagoinha and Maranduba rivers (Mahiques, 1995).

131 Since October 8, 2008, UBM, UBA and MV are parts of a Marine Protection Area 132 (MPA) (APA Marinha do Litoral - Cunhambebe Sector) created by the Ministry of 133 Environment (decree number 53.525). This MPA was established to ensure the conservation and 134 sustainable use of marine resources. Fishing is only permitted for the subsistence of traditional 135 communities, by amateurs, and as a leisure activity, thus, commercial fishing is not allowed. 136 These restrictions aim to protect the area and promote the rational use of its natural resources, 137 ensuring the region's sustainable development.

\section{Sampling}

We captured the swimming crabs monthly from January 1998 through December 1999. 140 In each bay, six sampling stations were established: three stations were located in areas sheltered from the waves $(5,7.5$ and $10 \mathrm{~m}$ deep), and three were located in exposed areas (10, 15 and $20 \mathrm{~m}$ deep) (Fig. 1). The stations (except the 7.5 and $10 \mathrm{~m}$ depths) were positioned along transects set parallel to the coastline. These stations were selected according to the following characteristics: their position relative to the bay's mouth, the presence of rocky shores or beaches along the bay's perimeter, freshwater inflow, proximity to offshore water, depth, and sediment texture.

Trawling was conducted on a commercial shrimp fishing boat outfitted with double-rig nets. Each area (18 sites) was trawled monthly (24 months) for 30 minutes and covered a total of $18,000 \mathrm{~m}^{2}$ per trawl. Individuals were identified to species level (Melo, 1996) and sorted by sex, based on abdominal morphological features (male $=$ triangular-shaped abdomen; female $=$ roundshaped abdomen), and number of pleopods (males = two pairs; females = four pairs). The animals were collected within the guidelines of the ICMBio-Instituto Chico Mendes de Conservação da Biodiversidade - Ministério do Meio Ambiente (Permit no. 44329715). 
At each station we took bottom and surface water samples using a Nansen bottle, and

154

155

156

157

158

159

160

161

162

163

164

165

166

167

168

169

170

171

172

173

174

175

176

177

178

179

180

181

182

183 measured salinity (\%) and temperature $\left({ }^{\circ} \mathrm{C}\right)$, using an optical refractometer and a mercury thermometer, respectively. Sediment samples were taken using a Van Veen grab, from which we obtained sediment texture and organic matter content. Depth was assessed with an echometer connected to a Global Positioning System (GPS). Immediately after collection, we put the sediment samples into labelled plastic bags and froze them to minimize the organic matter decomposition until further analyses.

Sediment analyses followed Hakanson \& Jansson (1983) and Tucker (1988). Two $50 \mathrm{~g}$ subsamples were taken, to which we added $250 \mathrm{ml}$ of $\mathrm{NaOH}(0.2 \mathrm{~N})$ to obtain the silt-clay fraction. We washed the subsamples using a sieve (0.063 $\mathrm{mm}$ mesh), washing away the silt-clay. The remaining sediment was dried and then differentially sieved, classifying the sediment grains according to the Wentworth (1922) scale.

Phi $(\varphi)$ values were calculated based on the equation $p h i=-\log _{2} d$, where $d=$ grain diameter (mm), thus obtaining the following classes: $-1 \mid-0$ (very coarse sand), $0 \mid-1$ (coarse sand), $1 \mid-2$ (intermediate sand), $2 \mid-3$ (fine sand), $3 \mid-4$ (very fine sand) e $>4$ (silt-clay). Based on these values we calculated the central trend measurements, determining the most frequent granulometric fractions in the sediment. We calculated these values based on data graphically taken from cumulative sediment samples frequency distribution curves. We used values corresponding to the $16^{\text {th }}, 50^{\text {th }}$ and $84^{\text {th }}$ percentages to determine the average diameter (AD), using the equation $A D=\left(\varphi_{16}+\varphi_{50}+\varphi_{84} / 3\right)$ (Suguio, 1973).

To determine the sediment organic matter content we put $10 \mathrm{~g}$ subsamples in porcelain containers, previously labelled and weighed. They were oven-dried $\left(500^{\circ} \mathrm{C}\right.$ for 3 hours $)$ and weighed. The difference between the initial and final weight indicated the organic matter content of each sampling station, what was later converted into percentages.

\section{Data analyses}

Our data were not normally distributed (Shapiro-Wilk, p >0.05) or homoscedastic (Levene's test, $\mathrm{p}>$ 0.05) (Samuel Sanford Shapiro \& Martin Wilk, 1965). Therefore, environmental factors $(\mathrm{BT}=$ bottom water temperature; $\mathrm{ST}=$ surface water temperature; $\mathrm{BS}=$ bottom water salinity; $\% \mathrm{OM}=$ percentage organic matter; and $\mathrm{Phi}=$ sediment texture) were compared between years using a Mann-Whitney test (significance level = 5\%). We compared BT, ST, BS, \%OM and Phi values between bays, sampling stations, and seasons (Summer: 
184 January to March, and so on) using a Kruskal-Wallis test, followed by Dunn's post-hoc test 185 (Kruskal \&Wallis, 1952). Comparisons of the total abundance between bays and between 186 stations were carried out using a Kruskal-Wallis test, followed by a post-hoc Dunn test 187 (significance level $=5 \%$ ).

188 We used a Redundancy Analysis (RDA) to detect possible relationships between the 189 abundance of $A$. spinimanus and the environmental variables. This analysis requires the existence 190 of, at least, two dependent variables. For that reason, we grouped the individuals into males (M) 191 and females $(\mathrm{F})$. The RDA produces final coordination scores that summarize the linear 192 relationship between the explanatory and response variables. Only environmental variables with 193 scores higher than 0.4 and lower than -0.4 were considered as biologically significant 194 (Rakocinski, Lyczkowski-Shultz \& Richardson, 1996). This analysis was performed using the 195 Vegan package for R (R Development Core Team, 2013).

196

\section{RESULTS}

The mean ST, BT and BS did not differ significantly between bays (Kruskal \& Wallis, p 199 $>0.05)$. However, significant differences in ST, BT and BS were observed between years and areas (Table 1).

The highest variation in BT and ST, in all bays, was seen in summer and spring 1998/1999 (Fig. 2). In all bays, at the stations in exposed areas (10, 15 and $20 \mathrm{~m}$ deep) we observed clear differences between ST and BT (thermocline), especially in spring 1999 (Fig. 2). During autumn and winter, neither ST nor BT varied with depth (Fig. 2).

Temporally, the highest BS values were recorded in summer and autumn 1998, while in 1999, the highest BS was observed only in autumn (Fig. 3). The highest BS values were recorded in the $20 \mathrm{~m}$ deep station (Fig. 3). Significant variations in BS were recorded only in 1999.

The presence of three water masses typically observed in the studied region is noticeable in the BS and BT diagrams. From these diagrams it can be said that $\mathrm{CW}$ was prevalent in both years and in all bays, while the influence of SACW and TW was noticed only in 1999 (Fig. 4 and 211 $5)$.

Grain size and organic matter content differed between bays and between sites (Fig. 6). There was a gradual increase in phi values from north to south, with mean phi values of 3.8, 4.4 and 5.5 in UBM, UBA and MV, respectively. The highest \%OM was recorded in UBA (5.9\%), 
215 followed by MV (4.5\%) and UBM (3.6\%). The $20 \mathrm{~m}$ depth had the lowest \%OM average value $216(3.3 \%)(\mathrm{p}<0.05)(\mathrm{phi}=3.0)$. With respect to the $10 \mathrm{~m}$ deep stations, we observed the highest $217 \% \mathrm{OM}(6.2 \%)$ and mean phi (5.3), i.e., \%OM increased as the sediment grain size decreased.

218 We captured 1,911 A. spinimanus individuals: 1,255 in 1998, and 656 in 1999. The 219 highest abundance was recorded in UBA (1,509), followed by UBM (351) and MV (51). The 220 abundance varied throughout the seasons, being the highest in fall and spring 1998 in UBA

221 (Table 2). When comparing the abundance between bays, we observed that MV had significantly 222 lower abundance ( $\mathrm{p}<0.01)$. In UBM, the highest abundance recorded in 1998 was in the $20 \mathrm{~m}$ 223 deep station, while in 1999, it was in the $15 \mathrm{~m}$ station. In UBA, the highest abundances in 1998 224 and 1999 were recorded in the $7.5 \mathrm{~m}$ deep station. In MV, even though we did not observe 225 significant differences in the abundance of swimming crabs between stations $(\mathrm{p}>0.05)$, 226 individuals were found in only two stations (7.5 and $20 \mathrm{~m}$ deep) (Fig. 7).

227 The results of the axis 1 in the RDA (which explained $92.3 \%$ of the variation in our data) 228 revealed that the sediment features (\%OM and Phi) were factors that mostly affected the 229 individuals' distribution in all studied bays, for both years (Table 3). Based on this analysis the 230 abundance of $A$. spinimanus is inversely proportional to phi value. The highest swimming crab 231 abundances were seen in stations with low and intermediate phi values, i.e. with heterogeneous 232 sediment, mainly composed of gravel, very coarse sand, coarse sand and medium sand.

233

\section{DISCUSSION}

Based on the water temperature and salinity recorded in this study, we can infer that the Coastal Water current prevailed in the three bays. This water mass is characterized by salinity under 36 and temperature higher than $20^{\circ} \mathrm{C}$ (Castro-Filho, Miranda \& Myao, 1987). The effects of the South Atlantic Central Waters and Tropical Water masses could only be noticed in the second year, 1999. The SACW is a cold water mass, with temperatures under $18^{\circ} \mathrm{C}$ and salinity lower than 36, which reaches the deepest layers of the coastal water column and generates a thermocline (Pires, 1992). In this study, this thermocline was more evident in exposed areas, especially during the spring 1999.

Several studies have reported the influence of SACW and its physicochemical characteristics over the temporal abundance of decapod crustaceans along the southeastern 
246 2015). In this study, we speculate that this water mass has a negative influence on the abundance

247 of $A$. spinimanus, as its decreased in summer and spring 1999 in UBA. UBA Bay seems to be

248 more vulnerable than UBM and MV bays with respect to the effects of oceanic currents as it has

249 no physical protection, such as islands nearby. The coastline geography and the presence of

250 islands seen along the northern coast of São Paulo can attenuate the incidence of cold currents on

251 the coast (Mahiques, 1995). Thus, as a consequence, the effects of SACW in UBA Bay are

252 stronger, and may explain why in 1999 in UBA A. spinimanus migrated towards sheltered areas.

253 Mantelatto \& Fransozo (2000), studying the same bay, showed that from September 1995

254 through August 1996, individuals of A. spinimanus were grouped in a more sheltered site located

255 in the inner portion of Ubatuba Bay (which was not included in this study).

256 Temperature is widely accepted as a limiting factor in the distribution of marine

257 organisms (Lewis \& Roer, 1988), since many metabolic and physiological processes in

258 crustaceans (such as molting, growth, and oocyte maturation) depend on this variable (Sastry,

259 1983). Previous studies (Santos, Negreiros-Fransozo \& Fransozo, 1994; Santos, 2000; Bertini \&

260 Fransozo, 2004; Lima et al., 2014), carried out in the same area as the present one, have also

261 seen evidenced of the bottom water temperature's influence on the biology of $A$. spinimanus.

262 In UBM Bay, the stations at 15-20 m deep were the only ones with sediment composed

263 of higher granulometric fractions. Thus, even though these sediments were exposed to the effects

264 of water masses, they were favorable to the establishment of $A$. spinimanus. As well, in the same

265 bay, at the same time as when this study was performed, it was possible to see a higher

266 abundance of Callinectes danae Smith, 1869 in the shallower sampling sites (Antunes et al.,

267 2015). Since Shinozaki-Mendes, Manghi \& Lessa (2012) state that $C$. danae displays agonistic

268 and territoriality behaviors, we speculate that this behavior may have hampered the

269 establishment of $A$. spinimanus in the same area. The abundance of one species in a certain place

270 may be considered an ecological response through its adaptations to both the environmental

271 factors and intra- and interspecific interactive processes (Shinozaki-Mendes, Manghi \& Lessa, 272 2012).

273 This study indicates the texture of the sediment as the main factor modulating the 274 distribution of $A$. spinimanus. In all sampled bays, $A$. spinimanus abundance was higher in the 275 stations composed mainly of heterogeneous sediment. This may be explained by the foraging and 276 refuge options created by the heterogeneous sediments: as the more heterogeneous the 
277 sediments are, the more microhabitats there are (Bertini, Fransozo \& Melo 2004). Previous

278 studies (Santos, Negreiros-Fransozo \& Fransozo, 1994; Bertini \& Fransozo, 2004; Furlan et al., 279 2013, for instance) have also described a higher abundance of $A$. spinimanus in areas where the 280 sediment texture was more heterogeneous.

281 The highest abundance of $A$. spinimanus was recorded in UBA $(78.9 \%$ of the total 282 number of individuals) in the $7.5 \mathrm{~m}$ deep station, which may be explained by the heterogeneous 283 texture of the sediment and a high percentage of organic matter of this station. According to 284 Moore (1958), areas with finer sediment grains may have a higher percentage of organic matter 285 when compared to the ones with coarser grains. However, we observed an association between 286 the higher granulometric fractions and the organic matter content levels, even though organic 287 content was also positively associated with the silt-clay fraction. The higher organic matter 288 content observed in the $7.5 \mathrm{~m}$ deep station is related to gravel-composed sediments, which are of 289 biogenic nature, comprised of the remains of mollusk shells, crustacean carapaces and 290 echinoderms.

291 Lima et al. (2014) studying A. spinimanus in UBA in 2000 found fewer crabs (402 292 individuals) than in any year examined in the present study, although they used the same sample effort as the present study. This is probably due to those authors did not sample in the 7.5-m deep sampling station. One may thus assume that sheltered areas with heterogeneous sediments may provide a favorable habitat to the establishment of $A$. spinimanus. Moreover, this station is naturally protected from fisheries as it has many natural obstacles such as rocks and coral fragments, which damage fishing gears. Thus, the lower fishing pressure could have contributed to the higher abundance of individuals there. Lower fishing pressure can promote habitat complexity, favoring the establishment of individuals (Kaiser et al., 2002; Fransozo et al., 2016).

Mantelatto et al. (2016) indicated that UBA stations with high diversity indexes are naturally protected against fishing due to the difficulty of carrying out trawls in the area, which consequently provides less exposure of the local benthic fauna to the actions caused by trawls. According to Kaiser et al. (2002), the impacts of trawling on ecosystems include the reduction of habitat complexity, and changes in species abundance and distribution patterns and overall benthic community structure. Furthermore, Fransozo et al. (2016) describes trawling as 306 destructive and destabilizing to benthic communities, since it is not selective (i. e. does not 
307 capture only the fishery's target) and jumbles the seafloor, displacing or removing many other 308 organisms from their natural environments.

309 The low abundance observed in MV can be related to the sediment features observed in 310 that bay. This bay's sediment is composed mainly of silt-clay brought from the continent, as 311 well as a consequence of the physical barriers formed mainly by the São Sebastião Channel, 312 together with Anchieta and Vitória islands. Accordingly, Santos, Negreiros-Fransozo \& 313 Fransozo et al. (1994) sampled 126 individuals of $A$. spinimanus in Fortaleza Bay (November 3141998 through October 1989), whereas Hiroki (2012), 20 years later (November 2008 through 315 October 2009), and using the same sampling procedure, collected only 5 individuals. It is 316 noteworthy that besides observing a lower abundance, Hiroki (2012) also observed a decrease of 317 the higher granulometric fractions (gravel, very coarse sand, coarse sand and intermediate sand).

318 Based on our investigation, we highlight the role that environmental factors such as the 319 sediment texture play in the establishment and development of $A$. spinimanus populations. 320 Portunoidea usually burrow in the sediment for protection against predators or to facilitate the 321 capture of fast prey (Schöne, 1961) such as fishes. Muddy sediments, however, make burrowing and the intake of water for gas exchange more difficult.

According to McNaughton \& Wolf (1970), the dominance of certain species in a given habitat may be explained mainly by two opposite hypotheses: (1) the dominant species are generalists and adapted to a wide variation in environmental conditions and therefore, are not limited by them; or (2) the dominant species are specialists and are well adapted to one or some aspects of their habitat. In the study carried out by Bertini, Fransozo \& Negreiros-Fransozo (2010), some species seemed to be generalists and not restricted to a certain type of substrate (e.g. Callinectes ornatus Ordway, 1968 and Hepatus pudibundus (Herbst, 1785)), while others were frequently associated with specific sediment types (e.g. Libinia ferreirae Brito Capello, 1871 and $A$. spinimanus). Despite its higher abundance in coarser sediments, A. spinimanus cannot be characterized as a stenotopic species until it is shown that the this crab is limited by a number of characteristics/ parameters.

\section{CONCLUSION}

Overall, this study broadens the knowledge on the sediment features most favorable to the 336 establishment and development of $A$. spinimanus populations. Moreover, it provides a basis for 
337 comparison with current data, and it also attests the efficiency of the implemented strategies in

$3382008-2009$ for the species conservation.

339

\section{ACKNOWLEDGEMENTS}

We thank NEBECC co-workers for their help during the fieldwork and Dr. Maria Lucia

Negreiros-Fransozo for her constructive comments and valuable grammar review of this manuscript.

\section{REFERENCES}

Abelló P, Valladares FJ, Castellón A. 1988. Analysis of the structure of decapod crustacean assemblages off the Catalan coast (North-West Mediterranean). Marine Biology 98:39-49 DOI 10.1007/BF00392657

Ab'Saber AN. 1955. Contribuição à geomorfologia do litoral paulista. Revista Brasileira de Geografia 17(1):3-48.

Almeida AC, Fransozo A, Teixeira GM, Hiroki KAN, Furlan M, Bertini G. 2012. Ecological distribution of the shrimp Nematopalaemon schmitti (Crustacea: Decapoda: Caridea) in three bays on the south-eastern coast of Brazil. African Journal of Marine Science 34:93102 DOI 10.2989/1814232X.2012.673292

Andrade LS, Frameschi IF, Costa RC, Castilho AL, Fransozo A. 2014. The assemblage composition and structure of swimming crabs (Portunoidea) in continental shelf waters of southeastern Brazil. Continental Shelf Research 94:8-16 DOI 10.1016/j.csr.2014.12.005

Andrade LS, Fransozo V, Cobo VJ, Castilho AL, Bertini G, Fransozo A. 2013. Ontogenetic distribution of Callinectes ornatus (Decapoda, Portunidae) in southeastern Brazil. Ciencias Marinas 39(4):371-385 DOI 10.7773/cm.v39i4.2280

Antunes M, Fransozo V, Bertini G, Teixeira GM, Fransozo A. 2015. Abundance and distribution of the swimming crab Callinectes danae Smith, 1869 (Crustacea, Decapoda, Portunidae) in the Ubatuba region, southeastern Brazil. Marine Biology Research 11(9):920-932 DOI 10.1080/17451000.2015.1044998

Bertini G, Fransozo A. 2004. Bathymetric distribution of brachyuran crab (Crustacea, Decapoda) communities on coastal soft bottom off southeastern Brazil. Marine Ecology Progress Series 279: 193-200 DOI 10.3354/mesps279193 
368

369

370

371

372

373

374

375

376

377

378

379

380

381

382

383

384

385

386

387

388

389

390

391

392

393

394

395

396

397

Bertini G, Fransozo A, Costa RC. 2001. Ecological distribution of three species of Persephona (Brachyura, Leucosiidae) in the Ubatuba region, São Paulo, Brazil. Nauplius 9(1):31-42

Bertini G, Fransozo A, Melo GAS. 2004. Biodiversity of brachyuran crabs (Crustacea: Decapoda) from non-consolidaded sublittoral bottom on the northern coast of São Paulo State, Brazil. Biodiversity \& Conservation 13(12):2185-2207 DOI 10.1023/B:BIOC.0000047900.96123.34

Bertini G, Fransozo A, Negreiros-Fransozo ML. 2010. Brachyuran soft-bottom assemblage from marine shallow waters in the southeastern Brazilian littoral. Marine Biodiversity 40(4):277-29 DOI 10.1007/s12526-010-0049-9

Bochini GL, Fransozo A, Castilho AL, Hirose GL, Costa RC. 2014. Temporal and spatial distribution of the commercial shrimp Litopenaeus schmitti (Dendrobranchiata: Penaeidae) in the south-eastern Brazilian coast. Journal of the Marine Biological Association of the United Kingdom 94:1001-08 DOI 10.1017/S0025315414000265

Braga AA, Fransozo A, Bertini G, Fumis PB. 2005. Composition and abundance of the crabs (Decapoda, Brachyura) off Ubatuba and Caraguatatuba, northern coast of São Paulo, Brazil. Biota Neotropica 5(2):45-78 DOI 10.1590/S1676-06032005000300004

Braga AA, Fransozo A, Bertini G, Fumis PB. 2007. Bathymetric distribution and recruitment of the spider crab Libinia spinosa H. Milne Edwards 1834 in the Ubatuba and Caraguatatuba regions, northern coast of São Paulo, Brazil (Crustacea, Brachyura, Majoidea, Pisidae). Senckenbergiana Biologica 87(1):7-16.

Branco JO, Fracasso HAA. 2004. Ocorrência e abundância da carcinofauna acompanhante na pesca do camarão sete-barbas Xiphopenaeus kroyeri (Heller, 1862) (Crustacea, Decapoda), na armação do Itapocoroy, Penha, Santa Catarina, Brasil. Revista Brasileira de Zoologia 21(2):295-301 DOI 10.1590/S0101-81752004000200022

Branco JO, Lunardon-Branco MJ, Souto FX. 2002. Estrutura populacional de Portunus spinimanus Latreille (Crustacea, Portunidae) na Armação do Itapocoroy, Penha, Santa Catarina, Brasil. Revista Brasileira de Zoologia 19(3):731-738 DOI 10.1590/S010181752004000200022

Cartes JE, Serrano A, Velasco F, Parra S, Sánchez F. 2007. Community structure and dynamics of deep-water decapod assemblages from Le Danois Bank (Cantabrian Sea, NE 
398

399

400

401

402

403

404

405

406

407

408

409

410

411

412

413

414

415

416

417

418

419

420

421

422

423

424

425

426

Atlantic): Influence of environmental variables and food availability. Progress in Oceanography 75:797-816 DOI 10.1016/j.pocean.2007.09.003

Castilho AL, Bauer RT, Freire FAM, Fransozo V, Costa RC, Grabowski RC, Fransozo A. 2015. Lifespan and reproductive dynamics of the commercially important sea bob shrimp Xiphopenaeus kroyeri (Penaeoidea): Synthesis of a 5-year study. Journal of Crustacean Biology 35:30-40 DOI 10.1163/1937240X-00002300

Castro-Filho BM, Miranda LB, Myao SY. 1987. Condições hidrográficas na plataforma continental ao largo de Ubatuba: variações sazonais e em média escala. Boletim do Instituto Oceanográfico 35(2):135-151 DOI:10.1590/S1679-87591987000200004

Cetesb (Companhia de Tecnologia de Saneamento Ambiental). 1996. Relatório de Balneabilidade das Praias Paulistas-1995. São Paulo: Secretaria do Meio Ambiente. 112 pages.

Chacur MM, Negreiros-Fransozo ML. 2001. Spatial and seasonal distributions of Callinectes danae (Decapoda, Portunidae) in Ubatuba Bay, São Paulo, Brazil. Journal of Crustacean Biology 21:414-25 DOI: $10.1163 / 20021975-99990142$

Costa RC, Carvalho-Batista A, Herrera DR, Pantaleão JAF, Teodoro SSA, Davanso TM. 2016. Carcinofauna acompanhante da pesca do camarão-sete barbas Xiphopenaeus kroyeri em Macaé, Rio de Janeiro, sudeste brasileiro. Boletim do Instituto de Pesca 42(3):1-13 DOI 10.20950/1678-2305.2016v42n3p611

Costa RC, Fransozo A, Freire FAM, Castilho AL. 2007. Abundance and ecological distribution of the "sete-barbas" shrimp Xiphopenaeus kroyeri (Heller, 1862) (Decapoda: Penaeoidea) in three bays of the Ubatuba region, southeastern Brazil. Gulf and Caribbean Research 19:33-41 DOI 10.18785/gcr.1901.04

De Léo FC, Pires-Vanin AMS. 2006. Benthic mega fauna communities under the influence of the South Atlantic Central Water intrusion on to the Brazilian SE shelf: A comparison between an upwelling and a non-upwelling ecosystem. Journal of Marine Systems 60: 268-84 DOI 10.1016/j.jmarsys.2006.02.002

D'incao F, Valentini H, Rodrigues ELF. 2002. Avaliação da pesca de camarões nas regiões Sudeste e Sul do Brasil. Atlântica 24:103-116. 
427 Fariña AC, Freire J, González-Gurriarán E. 1997. Megabenthic decapod crustacean

428

429

430

431

432

433

434

435

436

437

438

439

440

441

442

443

444

445

446

447

448

449

450

451

452

453

454

455

456

457

assemblages on the Galician continental shelf and upper slope (north-west Spain). Marine Biology 127:419-434 DOI 10.1007/s002270050029

Fransozo A, Sousa AN, Rodrigues GFB, Telles JN, Fransozo V, Negreiros-Fransozo ML. 2016. Crustáceos decápodes capturados na pesca do camarão-sete-barbas no sublitoral não consolidado do litoral norte do estado de São Paulo, Brasil. Boletim do Instituto de Pesca 42(2):369-386 DOI 10.5007/1678-2305.2016v42n2p369

Fransozo V, Silva TED, Fumis PB, Bertini G, Lima PAD. 2013. Ecological distribution and population structure of Acantholobulus schmitti (Rathbun, 1930) (Crustacea, Decapoda, Xanthoidea) on the southeastern Brazilian coast. Brazilian Journal of Oceanography 61(4):277-287 DOI 10.1590/S1679-87592013000400008

Furlan M, Castilho AL, Fernandes-Góes LC, Fransozo V, Bertini G, Costa RC. 2013. Effect of environmental factors on the abundance of decapod crustaceans from soft bottoms off southeastern Brazil. Anais da Academia Brasileira de Ciências 85(4):1345-1356 DOI $10.1590 / 0001-3765201394812$

Hakanson L, Jansson M. 1983. Principles of Lake Sedimentology. Germany: Springer-Verlag.

Hiroki KAN. 2012. Estrutura e dinâmica das comunidades de crustáceos decápodos no litoral norte do Estado de São Paulo. Doctoral Thesis. Instituto de Biociências de Botucatu, Brazil.

Kaiser MJ, Collie JS, Hall SJ, Jennings S, Poiner IR. 2002. Modification of marine habitats by trawling activities: prognosis and solutions. Fish and Fisheries 3:114-136 DOI 10.1046/j.1467-2979.2002.00079.x

Kruskal, WH, Wallis, WA. 1952. Use of ranks on one criterion variance analysis. Annals of Mathematical Statistics 30:271-294.

Lewis DH, Roer RD. 1988. Thermal preference in the distribution of blue crabs, Callinectes sapidus, in a power plant cooling pond. Journal of Crustacean Biology 8(2):283-289 DOI $\underline{10.2307 / 1548320}$

Lima PA, Andrade LS, Alencar CERD, Pereira RT, Teixeira GM, Fransozo A. 2014. Two species of swimming crabs of the genus Achelous (Crustacea, Brachyura): environmental requirements determining the niche. Hydrobiologia 727:197-207 DOI 10.1007/s10750014-1803-y 
458 459

460

461

462

463

464

465

466

467

468

469

470

471

472

473

474

475

476

477

478

479

480

481

482

483

484

485

486

Mahiques MM. 1995. Dinâmica sedimentar atual nas enseadas da região de Ubatuba, Estado de São Paulo. Boletim do Instituto Oceanográfico 43(2):111-122.

Mantelatto FLM, Bernardo CH, Silva TE, Bernardes VP, Cobo VJ, Fransozo A. 2016. Composição e distribuição de crustáceos decápodes associados à pesca do camarão-setebarbas Xiphopenaeus kroyeri (Heller, 1862) no litoral norte do estado de São Paulo. Boletim do Instituto de Pesca 42(2):307-326 DOI $\underline{10.5007 / 1678-}$ 2305.2016v42n2p307

Mantelatto FLM, Fransozo A. 2000. Brachyuran community in Ubatuba bay, northern coast of São Paulo State, Brazil. Journal of Shellfish Research 19(2):701-710. DOI 10.5007/16782305.2016v42n2p307

Martins BA, Pereira RT, Fransozo V, Teixeira GM, Furlan M, Fransozo A. 2014. Environmental factors modulating the abundance and distribution of Callinectes danae (Decapoda: Portunidae) from two areas of the southeastern coast of Brazil. Biologia 69(10):1356-1364 DOI 10.2478/s11756-014-0440-2

McNaughton SJ, Wolf LL. 1970. Dominance and the niche in ecological systems. Science 167:131-139 DOI 10.1126/science.167.3915.131

Melo GAS. 1996. Manual de Identificação dos Brachyura (caranguejos e siris) do Litoral Brasileiro. Plêiade: FAPESP.

Moore Hb. 1958. Marine Ecology. New York: Wiley \& Sons.

Negreiros-Fransozo ML, Fransozo A, Pinheiro MAA, Mantelatto FLM, Santos S. 1991. Caracterização física e química da Enseada de Fortaleza, Ubatuba, SP. Revista Brasileira de Geociências 21(2):114-120.

Odebrecht C, Castello JP. 2001. The convergency ecosystem in the southwest Atlantic. Coastal Marine Ecosystems of Latin America. Springer: Heidelberg.

Organista DE, Morrone JJ, Bousquets JL, Villela OF. 2005. Introducción al análisis de patrones em biogeografia histórica. Facultad de Ciencias: Las Prensas de Ciencias.

Pinheiro MAA, Fransozo A, Negreiros-Fransozo ML. 1996. Distribution patterns of Arenaeus cribrarius (Lamarck, 1818) (Crustacea, Portunidae) in Fortaleza Bay, Ubatuba (SP), Brazil. Revista Brasileira de Biologia 56:705-716. 
487

488

489

490

491

492

493

494

495

496

497

498

499

500

501

502

503

504

505

506

507

508

509

510

511

512

513

514

Pinheiro MAA, Fransozo A, Negreiros-Fransozo ML. 1997. Dimensionamento e sobreposição de nichos ecológicos dos portunídeos (Decapoda, Brachyura), na Enseada da Fortaleza, Ubatuba, São Paulo, Brasil. Revista Brasileira de Zoologia 14: 371-378.

Pires AMS. 1992. Structure and dynamics of benthic megafauna on the continental shelf offshore of Ubatuba, southeastern, Brazil. Marine Ecology Progress Series 86:63-76.

Pires-Vanin AMS, Matsuura Y. 1993. Estrutura e função do ecossistema de plataforma continental da região de Ubatuba, Estado de São Paulo: Uma introdução. Boletim do Instituto Oceanográfico 10:1-8.

R Development Core Team. 2013. R: A Language and Environment for Statistical Computing. R Foundation for Statistical Computing, Vienna. http://www.R-project.org. ISBN 3900051-07-0

Rakocinski CF, Lyczkowski-Shultz J, Richardson SL. 1996. Ichthyoplankton assemblage structure in Mississippi sound as revealed by canonical correspondence analysis. Estuarine, Coastal and Shelf Science 43:237-257 DOI 10.1006/ecss.1996.0067

Ripoli LV, Fernandes JM, Rosa DM, Araujo CCV. 2007. Dinâmica populacional de Portunus spinimanus Latreille, 1819 (Crustacea, Portunidae) em um trecho litorâneo da Ilha do Frade, Vitória - ES. Boletim do Instituto de Pesca 33(2):205-212.

Santos S. 2000. Influência dos fatores ambientais na abundância de Portunus spinimanus Latreille, 1819 (Crustacea, Brachyura, Portunidae) na enseada da Fortaleza, Ubatuba, SP. Ciência e Natura 22:129-144.

Santos S, Negreiros-Fransozo ML, Fransozo A. 1994. The distribution of the swimming crab Portunus spinimanus Latreille, 1819 (Crustacea Brachyura, Portunidae) in Fortaleza Bay, Ubatuba, SP, Brazil. Atlântica 16:125-141.

Santos S, Negreiros-Fransozo ML, Padovani CR. 1995. Relação do peso em função da largura da carapaça do siri candeia Portunus spinimanus Latreille, 1819 (Decapoda Portunidae). Arquivos de Biologia e Tecnologia 38(3):715-724.

Sastry AN. 1983. Ecological aspects of reproduction. The biology of Crustacea: Environmental adaptations. New York: Academic Press, 179-270. 
515 Shapiro, SS, Wilk, MB. 1965. An analysis of variance test for normality. Biometrika 52(3):

516 591-611 DOI $10.2307 / 2333709$

517 Shinozaki-Mendes RA, Manghi RF, Lessa R. 2012. The influence of environmental factors on

518 the abundance of swimming crabs (Brachyura, Portunidae) in tropical estuary,

519 Northeastern Brazil. Crustaceana 85(11):1317-1331. DOI 10.1163/156854012X651510

520 Schöne H. 1961. Complex behavior. The Physiology of Crustacea. Sense Organs, Integration 521 and Behaviour : Academic Press.

522 Suguio K. 1973. Introdução à Sedimentologia. Edgard Blucher: EDUSP.

523 Thompson JD. 1991. Phenotypic plasticity as a component of evolutionary chance. Tree 6:246524249 DOI $\underline{10.1016 / 0169-5347(91) 90070-\mathrm{E}}$

525 Tucker M. 1988. Techniques in Sedimentology. Melbourne: Blackwell Scientific Publications.

526 Wentworth CK. 1922. A scale of grade and class terms for clastic sediments. Journal of 527 Geology 30:377-92 DOI 1 10.1086/622910

528 Zar JH. 1999. Biostatistical Analysis. Englewood Cliffs: Prentice-Hall. 


\section{Table $\mathbf{1}$ (on next page)}

Mean values ( \pm standard deviation) for the environmental factors (ST, BT and BS) and results from the Kruskal-Wallis and Mann-Whitney test.

BT = Bottom water temperature; ST = Surface water temperature; BS = Bottom water salinity; $\mathrm{H}=$ Kruskal-Wallis test; $\mathrm{U}=$ Mann-Whitney test. 


\begin{tabular}{|c|c|c|c|c|}
\hline & & $\mathrm{ST} \pm \mathrm{SD}$ & $\mathrm{BT} \pm \mathrm{SD}$ & $\mathbf{B S} \pm \mathrm{SD}$ \\
\hline \multirow{3}{*}{ Bays } & Ubatumirim & $25.0 \pm 2.9$ & $22.9 \pm 2.8$ & $34.8 \pm 1.3$ \\
\hline & Ubatuba & $25.0 \pm 2.9$ & $23.2 \pm 2.8$ & $34.8 \pm 1.4$ \\
\hline & Mar Virado & $24.6 \pm 2.9$ & $22.8 \pm 2.8$ & $34.2 \pm 1.5$ \\
\hline \multicolumn{2}{|c|}{ Test value /p } & $\mathrm{H}=1.806 / \mathrm{p}=0.405$ & $\mathrm{H}=1.529 / \mathrm{p}=0.465$ & $\mathrm{H}=0.602 / \mathrm{p}=0.740$ \\
\hline \multirow{2}{*}{ Area } & Sheltered & $25.2 \pm 2.9$ & $23.7 \pm 2.7$ & $34.4 \pm 1.5$ \\
\hline & Exposed & $24.6 \pm 2.9$ & $22.3 \pm 2.8$ & $34.8 \pm 1.3$ \\
\hline \multicolumn{2}{|c|}{ Test value /p } & $\mathrm{U}=20095.5 / \mathrm{p}=0.010$ & $\mathrm{U}=16823.0 / \mathrm{p}<0.001$ & $\mathrm{U}=18339.0 / \mathrm{p}<0.001$ \\
\hline \multirow{2}{*}{ Year } & 1998 & $25.2 \pm 2.6$ & $23.3 \pm 2.4$ & $34.7 \pm 1.4$ \\
\hline & 1999 & $24.6 \pm 3.2$ & $22.6 \pm 3.2$ & $34.5 \pm 1.5$ \\
\hline \multicolumn{2}{|c|}{ Test value /p } & $\mathrm{U}=19915.5 / \mathrm{p}<0.001$ & $\mathrm{U}=19067.0 / \mathrm{p}<0.001$ & $\mathrm{U}=20550.0 / \mathrm{p}<0.001$ \\
\hline
\end{tabular}

1 


\section{Table 2 (on next page)}

Achelous spinimanus (Latreille, 1819). Number of individuals in each month and station sampled, indicating the results from the Dunn test (Columns with one same capital letter in common did not differ statistically, $p>0.05$ ). 


\begin{tabular}{|c|c|c|c|c|c|c|c|c|c|c|c|c|c|c|c|c|c|}
\hline \multicolumn{18}{|c|}{ Ubatumirim } \\
\hline \multirow[b]{3}{*}{ Season } & \multirow[b]{3}{*}{ Month } & \multicolumn{6}{|c|}{1998} & \multirow{2}{*}{\multicolumn{2}{|c|}{ Total }} & \multicolumn{8}{|c|}{1999} \\
\hline & & \multicolumn{3}{|c|}{ Sheltered area } & \multicolumn{3}{|c|}{ Exposed area } & & & \multicolumn{3}{|c|}{ Sheltered area } & \multicolumn{3}{|c|}{ Exposed area } & \multicolumn{2}{|c|}{ Total } \\
\hline & & $5 \mathrm{~m}$ & $7.5 \mathrm{~m}$ & $10 \mathrm{~m}$ & $10 \mathrm{~m}$ & $15 \mathrm{~m}$ & $20 \mathrm{~m}$ & Month & Season & $5 \mathrm{~m}$ & $7.5 \mathrm{~m}$ & $10 \mathrm{~m}$ & $10 \mathrm{~m}$ & $15 \mathrm{~m}$ & $20 \mathrm{~m}$ & Month & Season \\
\hline \multirow{3}{*}{ Summer } & Jan & 0 & 6 & 3 & 0 & 8 & 3 & 20 & \multirow{3}{*}{56} & 1 & 1 & 0 & 1 & 6 & 2 & 11 & \\
\hline & Feb & 0 & 10 & 2 & 1 & 9 & 2 & 24 & & 0 & 0 & 3 & 0 & 30 & 7 & 40 & 61 \\
\hline & Mar & 0 & 1 & 1 & 1 & 0 & 9 & 12 & & 0 & 0 & 6 & 0 & 1 & 3 & 10 & 61 \\
\hline & Apr & 0 & 0 & 1 & 0 & 1 & 8 & 10 & & 0 & 0 & 1 & 3 & 29 & 1 & 34 & \\
\hline Autumn & May & 0 & 2 & 0 & 0 & 7 & 1 & 10 & 37 & 0 & 0 & 0 & 0 & 7 & 4 & 11 & 54 \\
\hline & Jun & 0 & 10 & 0 & 0 & 2 & 5 & 17 & & 0 & 1 & 0 & 0 & 3 & 5 & 9 & \\
\hline & Jul & 0 & 5 & 0 & 1 & 0 & 1 & 7 & & 0 & 0 & 0 & 1 & 3 & 3 & 7 & \\
\hline Winter & Aug & 0 & 0 & 0 & 0 & 5 & 8 & 13 & 28 & 0 & 0 & 0 & 0 & 6 & 7 & 13 & 26 \\
\hline & Sep & 0 & 2 & 0 & 0 & 2 & 4 & 8 & & 0 & 0 & 0 & 0 & 4 & 2 & 6 & \\
\hline & Oct & 0 & 0 & 0 & 0 & 3 & 23 & 26 & & 0 & 0 & 0 & 0 & 6 & 20 & 26 & \\
\hline Sprıng & Nov & 0 & 2 & 0 & 2 & 4 & 2 & 10 & 39 & 0 & 1 & 1 & 4 & 3 & 3 & 12 & 50 \\
\hline & Dec & 0 & 1 & 0 & 0 & 2 & 0 & 3 & & 0 & 1 & 0 & 0 & 6 & 5 & 12 & \\
\hline Tot & & 0 & 39 & 7 & 5 & 43 & 66 & 160 & 160 & 1 & 4 & 11 & 9 & 104 & 62 & 191 & 191 \\
\hline Duun & Test & $\mathrm{A}$ & $\mathrm{BC}$ & $\mathrm{AB}$ & $\mathrm{AB}$ & $\mathrm{BC}$ & $\mathrm{C}$ & & & $\mathrm{A}$ & $\mathrm{A}$ & $\mathrm{A}$ & $\mathrm{A}$ & $\mathrm{B}$ & $\mathrm{B}$ & & \\
\hline & & & & & & & & Ubatub & & & & & & & & & \\
\hline & & & ltered & & & posed & & To & tal & & Itered a & & & posed a & rea & To & tal \\
\hline Season & Month & $5 \mathrm{~m}$ & $7.5 \mathrm{~m}$ & $10 \mathrm{~m}$ & $10 \mathrm{~m}$ & $15 \mathrm{~m}$ & $20 \mathrm{~m}$ & Month & Season & $5 \mathrm{~m}$ & $7.5 \mathrm{~m}$ & $10 \mathrm{~m}$ & $10 \mathrm{~m}$ & $15 \mathrm{~m}$ & $20 \mathrm{~m}$ & Month & Season \\
\hline & Jan & 1 & 7 & 0 & 1 & 1 & 0 & 10 & & 5 & 9 & 0 & 1 & 0 & 10 & 25 & \\
\hline Summer & Feb & 1 & 30 & 0 & 0 & 1 & 31 & 63 & 138 & 0 & 0 & 1 & 2 & 3 & 12 & 18 & 69 \\
\hline & Mar & 0 & 56 & 1 & 0 & 0 & 8 & 65 & & 0 & 11 & 0 & 0 & 0 & 15 & 26 & \\
\hline Autumn & Apr & 0 & 129 & 0 & 0 & 1 & 8 & 138 & & 1 & 52 & 0 & 0 & 0 & 5 & 58 & \\
\hline Autumn & May & 0 & 127 & 0 & 0 & 0 & 7 & 134 & 496 & 0 & 35 & 1 & 0 & 0 & 1 & 37 & 112 \\
\hline & Jun & 1 & 206 & 0 & 0 & 1 & 16 & 224 & 490 & 0 & 8 & 0 & 0 & 0 & 9 & 17 & 112 \\
\hline Winter & Jul & 0 & 42 & 0 & 0 & 0 & 4 & 46 & & 2 & 28 & 0 & 0 & 1 & 2 & 33 & \\
\hline Winter & Aug & 0 & 24 & 0 & 0 & 0 & 13 & 37 & 100 & 0 & 44 & 0 & 0 & 0 & 6 & 50 & 125 \\
\hline & Sep & 0 & 14 & 0 & 0 & 0 & 3 & 17 & 100 & 0 & 39 & 0 & 0 & 0 & 3 & 42 & 125 \\
\hline Spring & Oct & 0 & 31 & 0 & 0 & 1 & 12 & 44 & & 2 & 11 & 0 & 0 & 2 & 8 & 23 & \\
\hline Spring & Nov & 0 & 26 & 0 & 0 & 2 & 8 & 36 & 324 & 0 & 25 & 0 & 0 & 1 & 11 & 37 & 145 \\
\hline & Dec & 2 & 234 & 0 & 0 & 1 & 7 & 244 & & 0 & 74 & 0 & 0 & 0 & 11 & 85 & \\
\hline Tot & & 5 & 926 & 1 & 1 & 8 & 117 & 1058 & 1058 & 10 & 336 & 2 & 3 & 7 & 93 & 451 & 451 \\
\hline Duun & Test & $\mathrm{A}$ & $\mathrm{B}$ & $\mathrm{A}$ & $\mathrm{A}$ & $\mathrm{AC}$ & $\mathrm{BC}$ & & & $\mathrm{A}$ & $\mathrm{B}$ & $\mathrm{A}$ & $\mathrm{A}$ & $\mathrm{A}$ & $\mathrm{B}$ & & \\
\hline & & & & & & & & Mar Vira & ado & & & & & & & & \\
\hline & & & eltered & & & posed : & & To & tal & & tered a & rea & $\operatorname{Exp}$ & posed al & rea & To & tal \\
\hline Season & Month & $5 \mathrm{~m}$ & $7.5 \mathrm{~m}$ & $10 \mathrm{~m}$ & $10 \mathrm{~m}$ & $15 \mathrm{~m}$ & $20 \mathrm{~m}$ & Month & Season & $5 \mathrm{~m}$ & $7.5 \mathrm{~m}$ & $10 \mathrm{~m}$ & $10 \mathrm{~m}$ & $15 \mathrm{~m}$ & $\quad 20 \mathrm{~m}$ & Month & Season \\
\hline & Jan & 0 & 6 & 0 & 0 & 0 & 16 & 22 & & 0 & 1 & 0 & 0 & 1 & 1 & 3 & \\
\hline Summer & Feb & 0 & 3 & 0 & 0 & 0 & 7 & 10 & 32 & 0 & 0 & 0 & 0 & 0 & 1 & 1 & \\
\hline & Mar & 0 & 0 & 0 & 0 & 0 & 0 & 0 & & 0 & 0 & 0 & 0 & 0 & 5 & 5 & 9 \\
\hline & Apr & 0 & 0 & 0 & 0 & 0 & 0 & 0 & & 0 & 0 & 0 & 0 & 0 & 2 & 2 & 5 \\
\hline Autumn & May & 0 & 0 & 0 & 0 & 0 & 0 & 0 & 1 & 0 & 0 & 0 & 0 & 0 & 3 & 3 & 5 \\
\hline & Jun & 0 & 1 & 0 & 0 & 0 & 0 & 1 & & 0 & 0 & 0 & 0 & 0 & 0 & 0 & \\
\hline & Jul & 0 & 0 & 0 & 0 & 0 & 1 & 1 & & 0 & 0 & 0 & 0 & 0 & 0 & 0 & \\
\hline Winter & Aug & 0 & 0 & 0 & 0 & 0 & 0 & 0 & 2 & 0 & 0 & 0 & 0 & 0 & 0 & 0 & 0 \\
\hline & Sep & 0 & 1 & 0 & 0 & 0 & 0 & 1 & & 0 & 0 & 0 & 0 & 0 & 0 & 0 & \\
\hline & Oct & 0 & 1 & 0 & 0 & 0 & 0 & 1 & & 0 & 0 & 0 & 0 & 0 & 0 & 0 & \\
\hline Spring & Nov & 0 & 0 & 0 & 0 & 0 & 0 & 0 & 2 & 0 & 0 & 0 & 0 & 0 & 0 & 0 & 0 \\
\hline & Dec & 0 & 1 & 0 & 0 & 0 & 0 & 1 & & 0 & 0 & 0 & 0 & 0 & 0 & 0 & \\
\hline Tot & & 0 & 13 & 0 & 0 & 0 & 24 & 37 & 37 & 0 & 1 & 0 & 0 & 1 & 12 & 14 & 14 \\
\hline Duun & Test & & & & & & $n-s$ & ficant & value & $\mathrm{ne} \mathrm{K}$ & kal - & lis tes & & & & & \\
\hline
\end{tabular}




\section{Table 3(on next page)}

Achelous spinimanus (Latreille, 1819). Results from the redundancy analysis (RDA): ordination of the first two canonical axes, with environmental variable data and demographic categories' abundance from Ubatumirim, Ubatuba and Mar Virado.

Coefficients greater than or equal to +0.4 or lower than or equal to -0.4 were considered ecologically relevant (see Rakocinski, Lyczkowski-Shultz \& Richardson et al., 1996) and are shown in bold. 
1

\begin{tabular}{lcc}
\hline \hline & Axis 1 & Axis 2 \\
\hline Eigenvalue & 0.020 & 0.001 \\
\% of Variance & 0.923 & 0.076 \\
\hline Demographic categories & & \\
\hline Males & -0.329 & -0.159 \\
Females & -0.554 & 0.094 \\
\hline Environmental variables & & \\
\hline Bottom temperature & 0.040 & -0.958 \\
Bottom salinity & 0.080 & 0.139 \\
Organic matter & $\mathbf{- 0 . 4 1 8}$ & -0.450 \\
Phi & $\mathbf{0 . 6 8 5}$ & -0.523 \\
\hline \hline
\end{tabular}

2 
Figure 1

Map of the Ubatuba region (northeastern coast of São Paulo State), Brazil, showing the three bays and their respective sampling stations and depths (adapted from Fransozo et al. 2013).

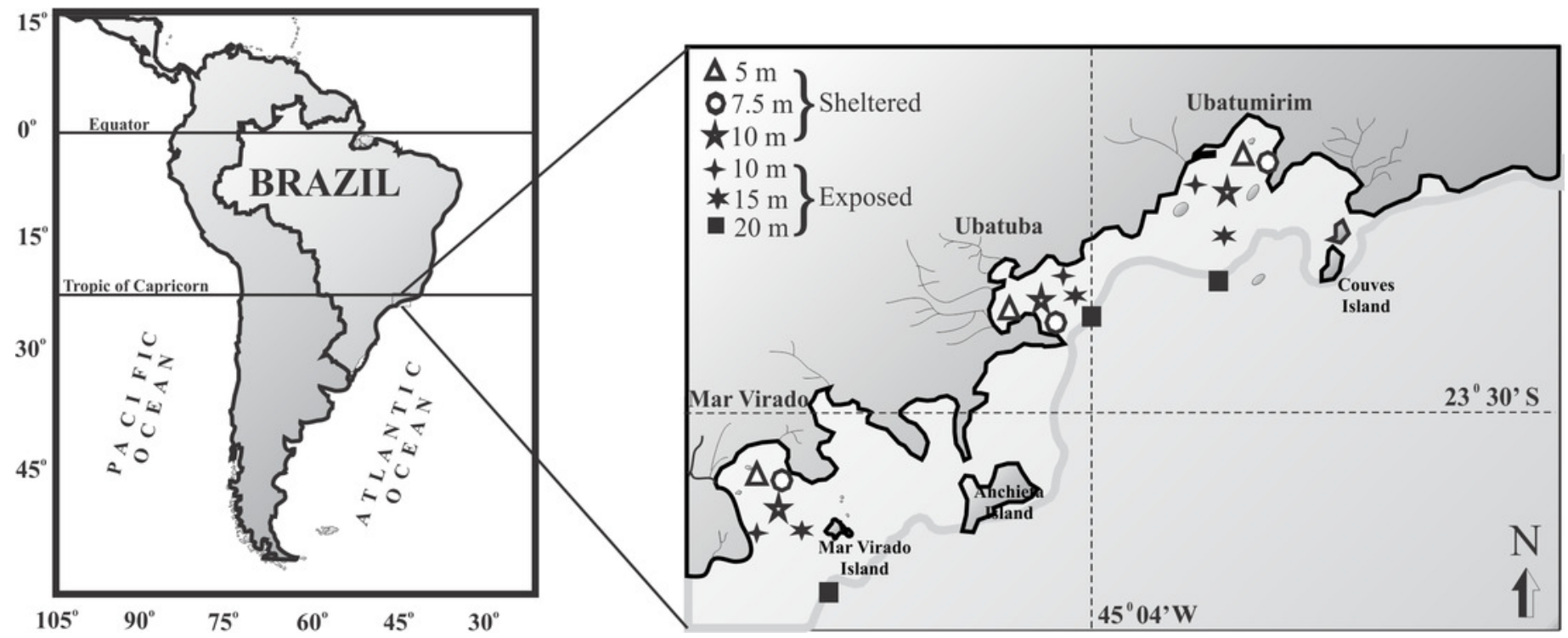


Figure 2

Bottom and surface temperature variation per seasons, areas and stations in 1998 and 1999.

(A) Ubatumirim Bay. (B) Ubatuba Bay. (C) Mar Virado Bay. (BT) Bottom temperature. (ST) Surface temperature

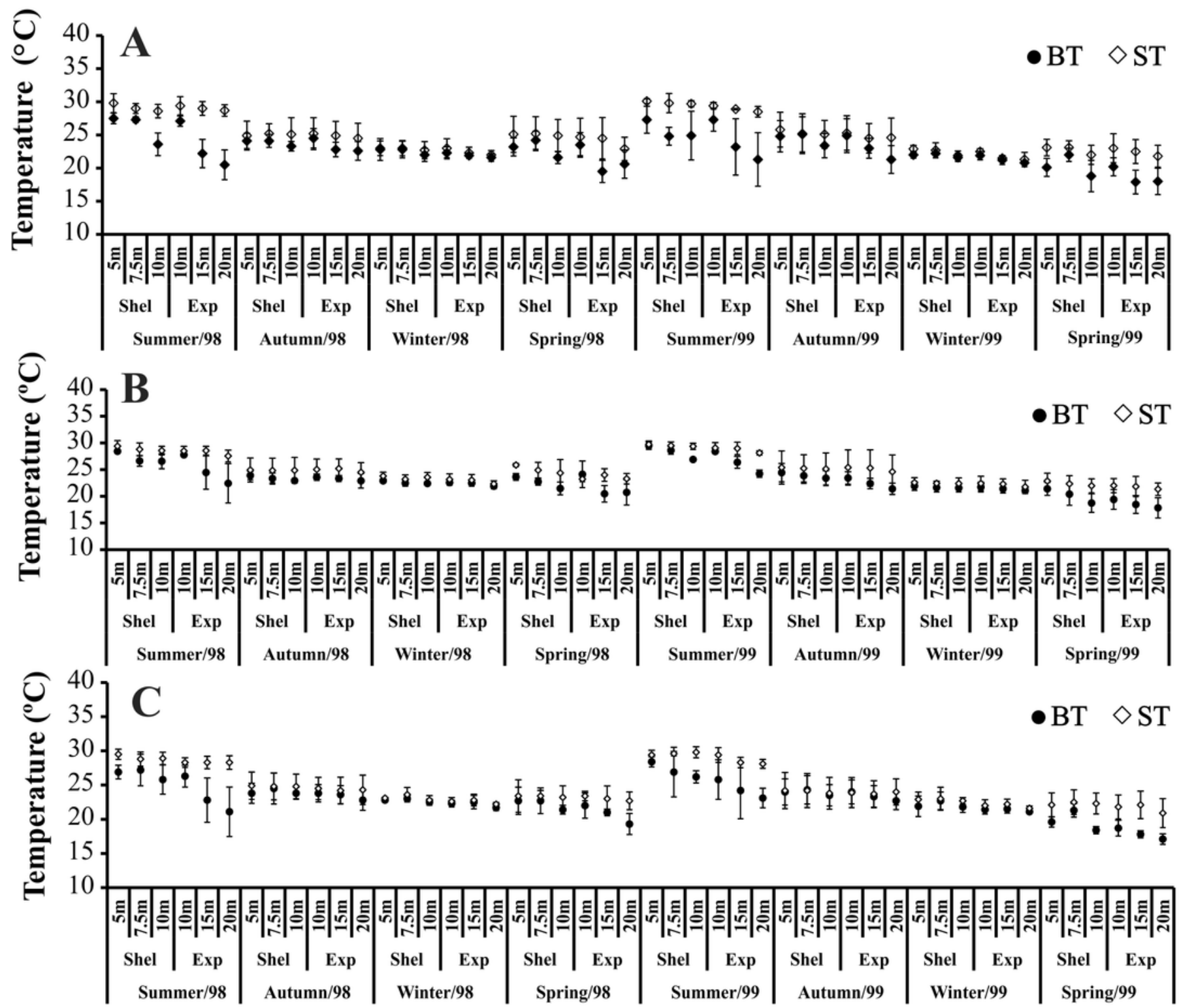


Figure 3

Bottom salinity variation per seasons, areas and stations in 1998 and 1999.

(A) Ubatumirim Bay. (B) Ubatuba Bay. (C) Mar Virado Bay.

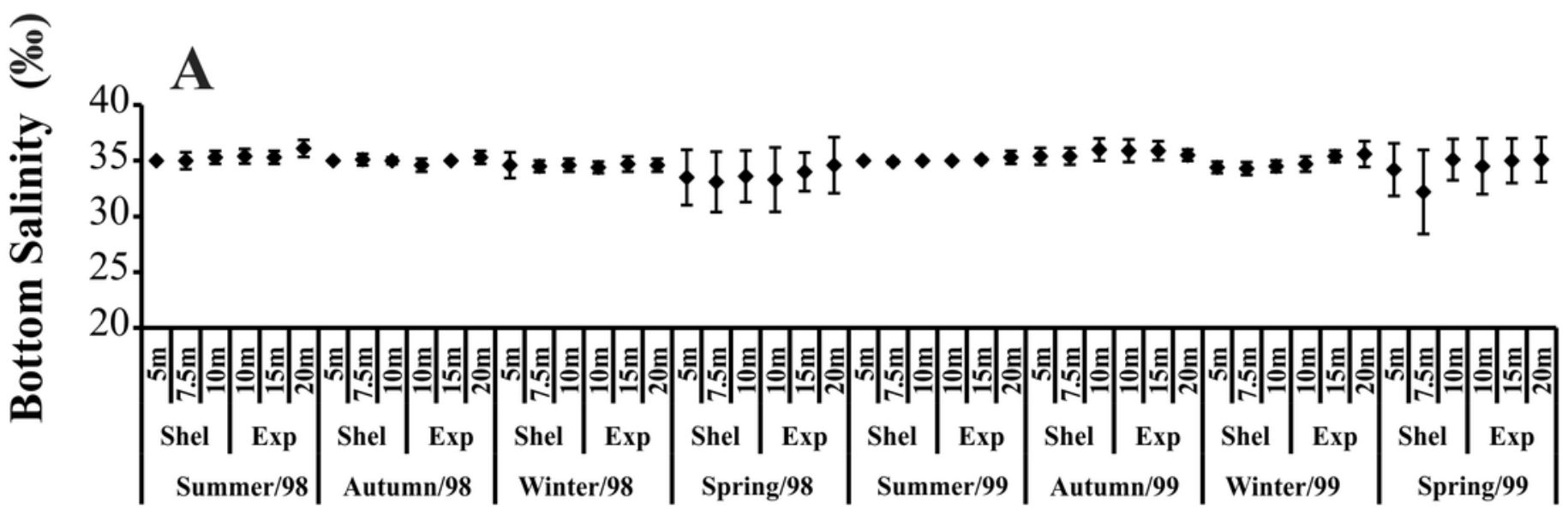

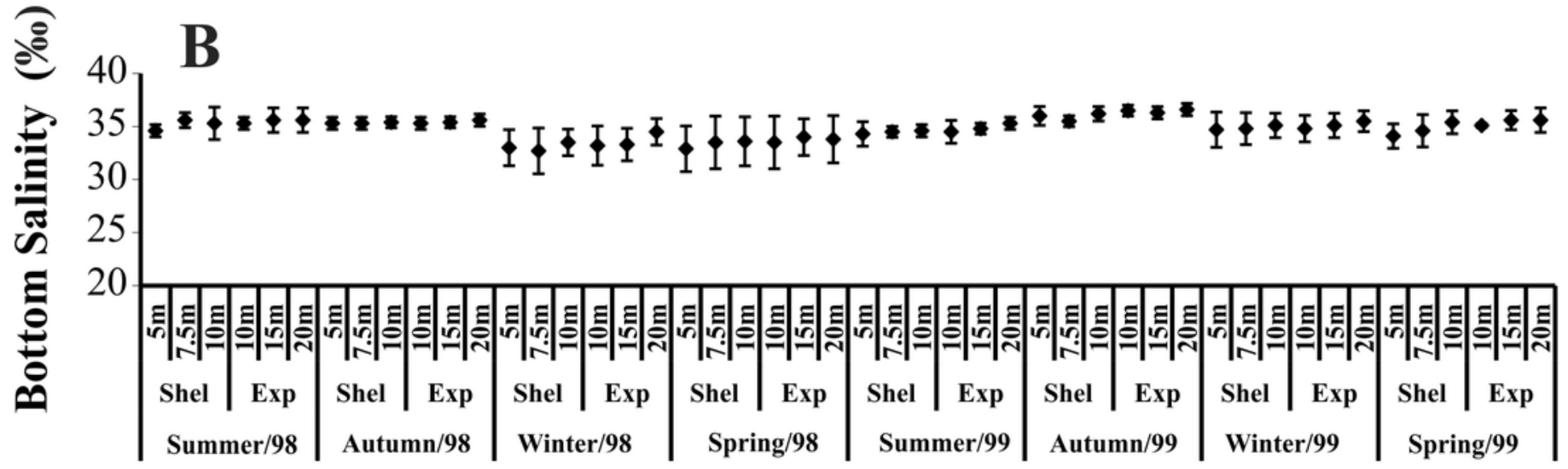

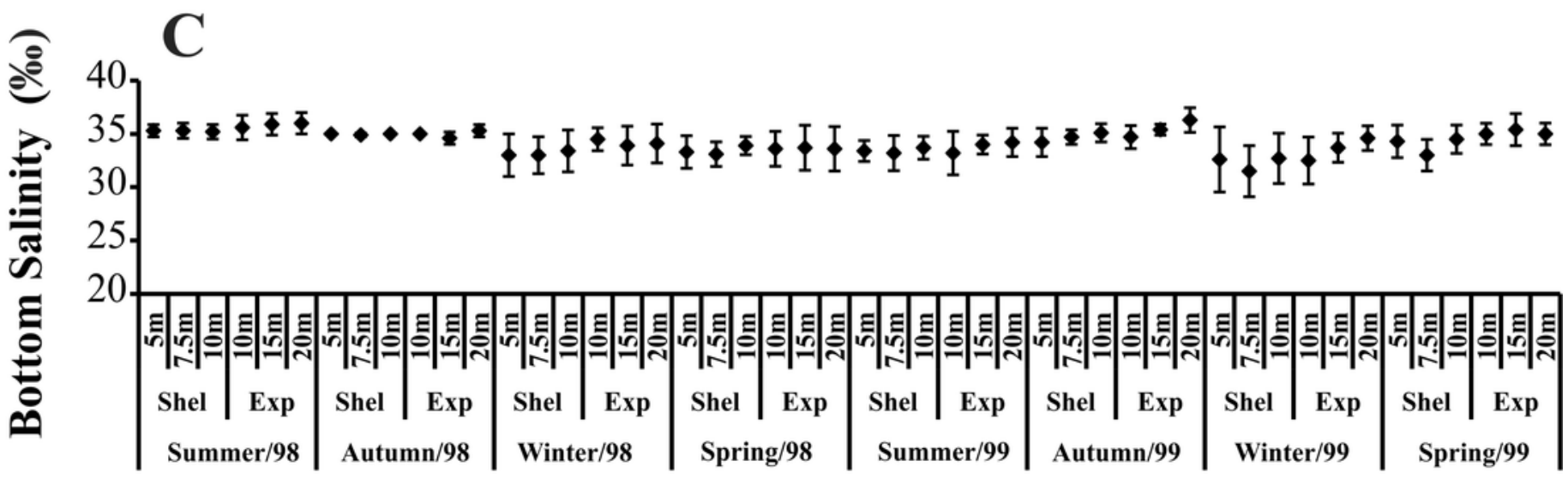




\section{Figure 4}

Diagram showing the seasonal variation of water temperature and salinity from January 1998 to December 1998, at Ubatumirim, Ubatuba and Mar Virado, São Paulo State littoral, southeastern coast of Brazil.

(A) Ubatumirim Bay. (B) Ubatuba Bay. (C) Mar Virado Bay. (CW) Coastal Water. (TW) Tropical Water. (SACW) South Atlantic Central Water. 

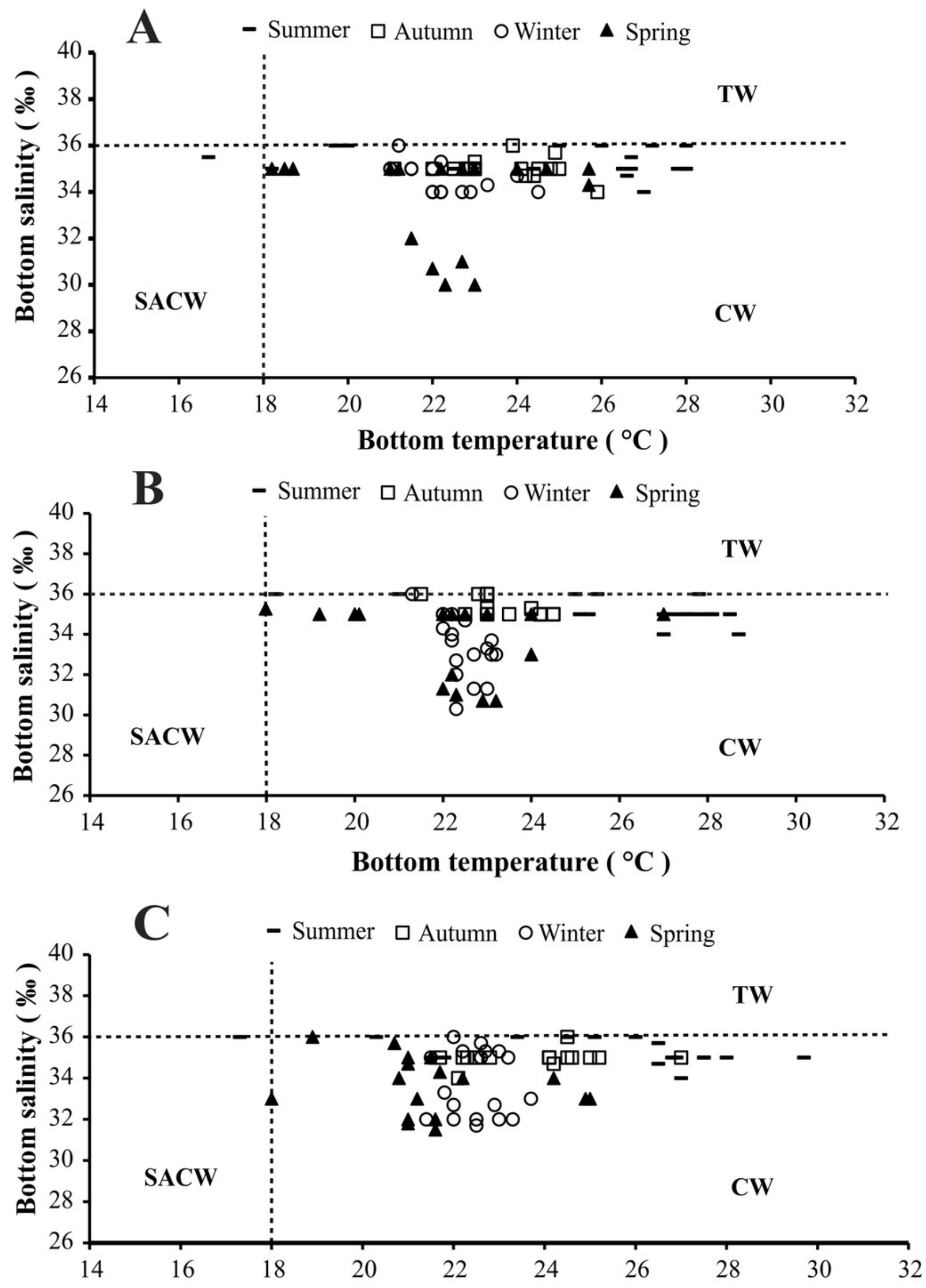


\section{Figure 5}

Diagram showing the seasonal variation of water temperature and salinity from January 1999 to December 1999, at Ubatumirim, Ubatuba and Mar Virado, São Paulo State littoral, southeastern coast of Brazil.

(A) Ubatumirim Bay. (B) Ubatuba Bay. (C) Mar Virado Bay. (CW) Coastal Water. (TW) Tropical Water. (SACW) South Atlantic Central Water. 

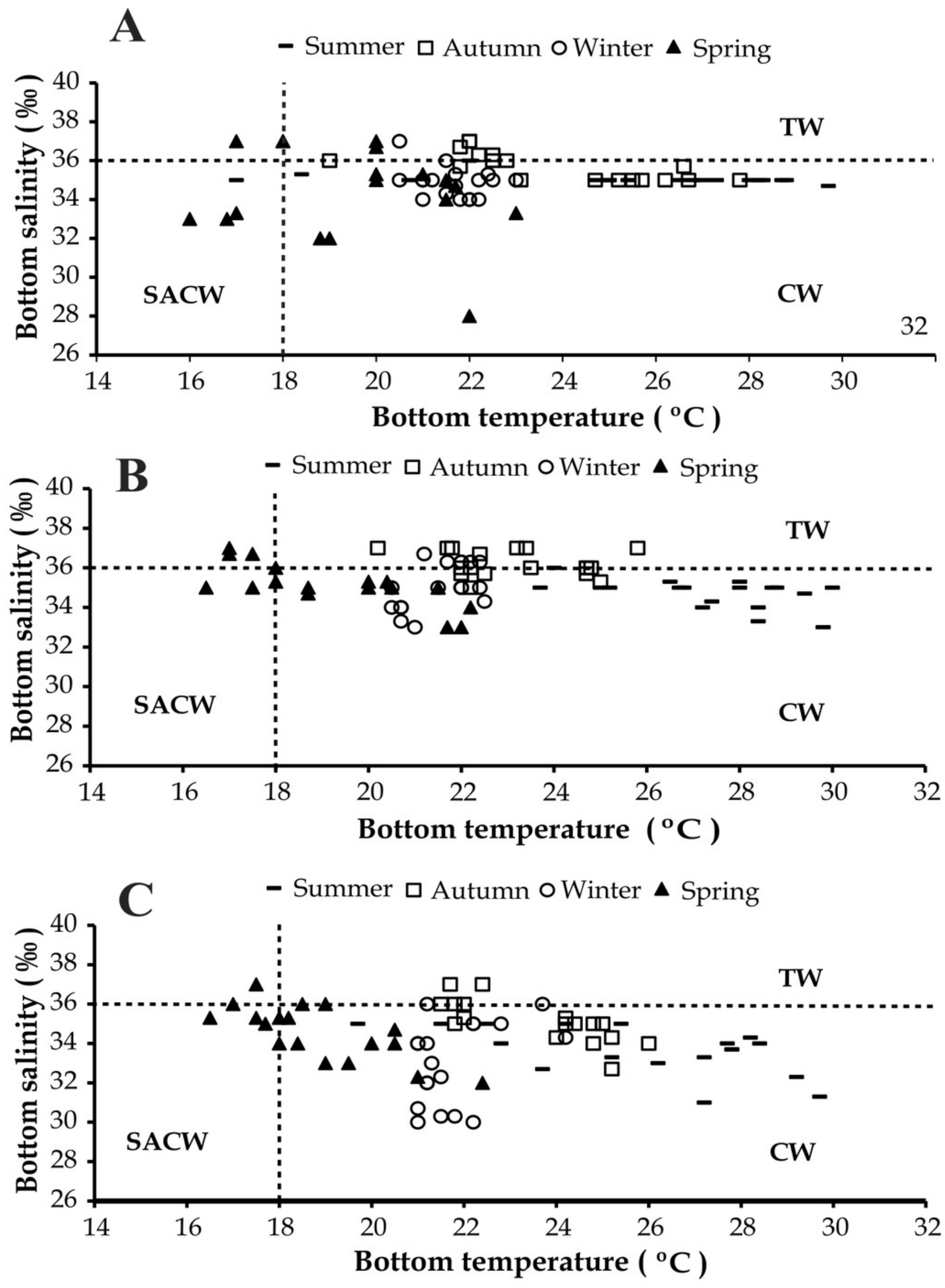


\section{Figure 6}

Proportions of grain-size classes, central tendency of bottom sediments (phi) and mean values of the organic matter content of the sediment (\% OM) for each depth in Ubatumirim, Ubatuba and Mar Virado, São Paulo State littoral, southeastern Brazil.

(A) Class A (gravel, very coarse sand, coarse sand, and intermediate sand). (B) Class B (fine and very fine sand). (C) Class C (silt-clay).

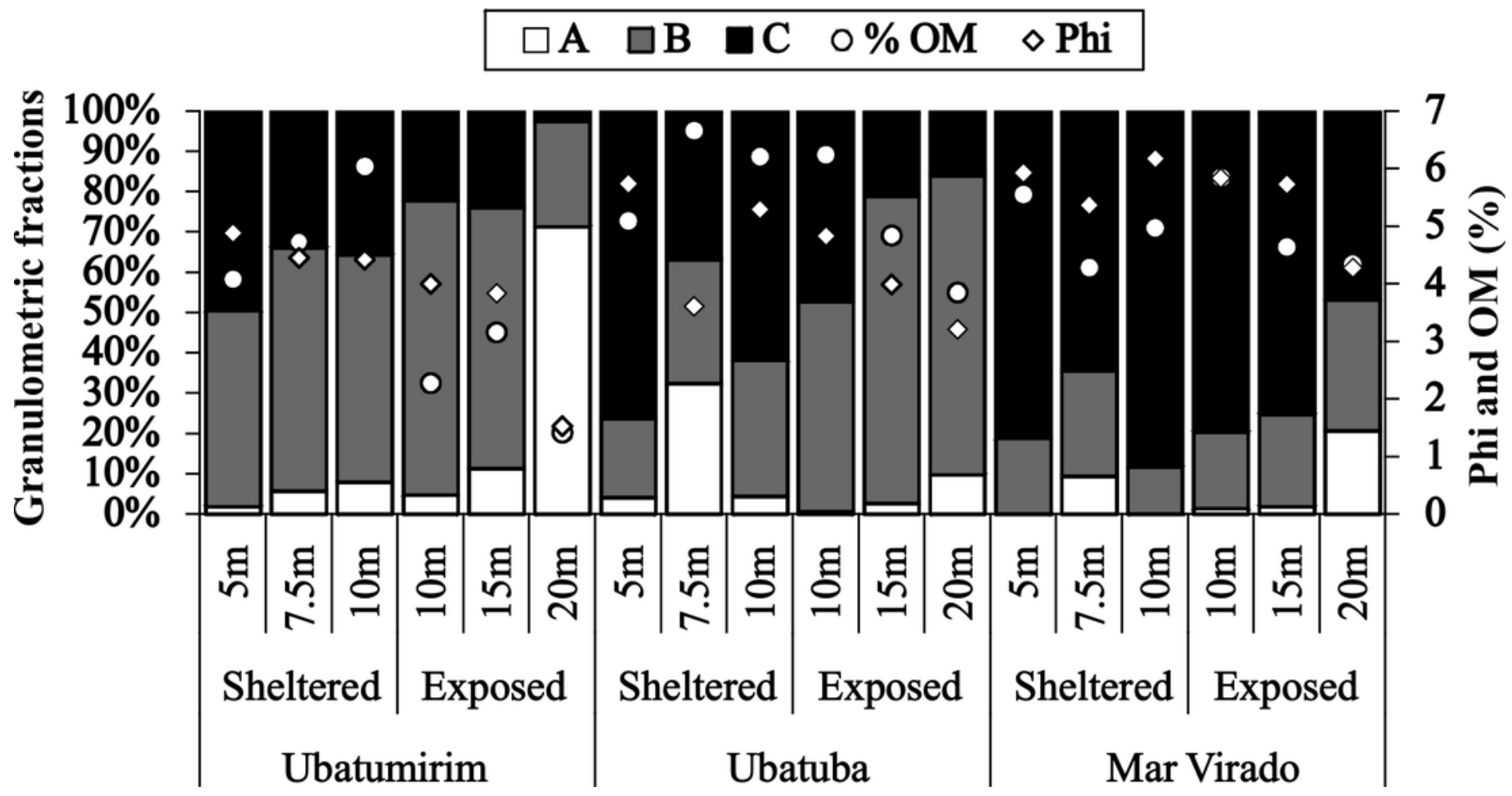


Figure 7 (on next page)

Achelous spinimanus(Latreille, 1819). Percentage of individuals in each season in the different bays and in each depth. Circle sizes are proportional to the percentages of individuals.

(Exp) exposed. (She) sheltered. 


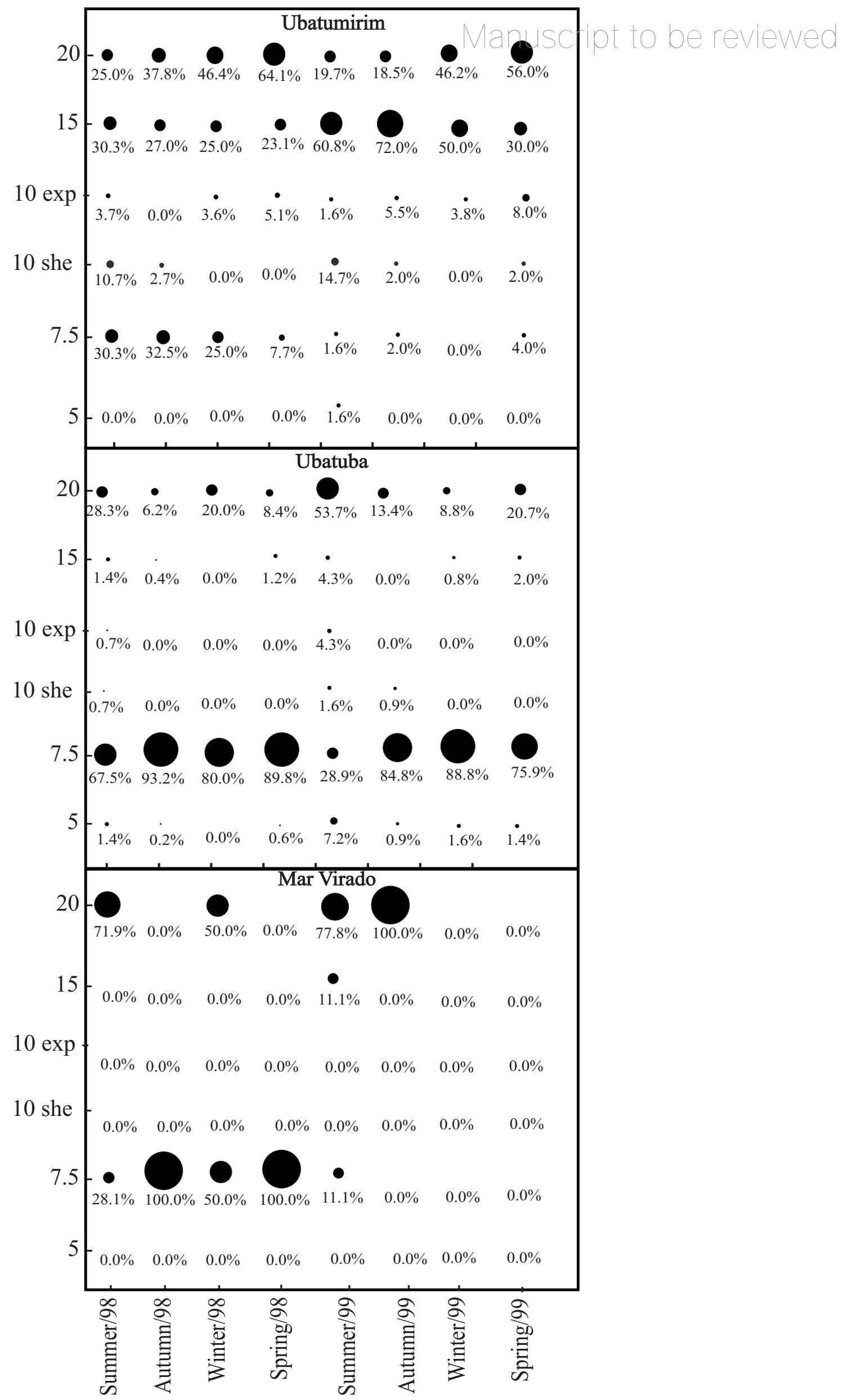

